\title{
Standardization method for teaching yoga meditation and asanas: a case study
}

\begin{abstract}
Yoga is a codex of exercises for the body and mind originated in India. It has a series of benefits for health. However, it is challenging to find a standardized system of meditation and asanas, with a simple application so that it is readily applicable to a large population, as well as easy scientific reproducibility. Aiming to test a reproducible 8-week Yoga learning model, two healthy male subjects, one with 51 and the other with 54 years old, underwent eight sessions of meditation and carefully selected asanas for secure execution. Evaluations occurred before the first session and one day after the last session. The measured variables were blood pressure, heart rate, and global stretch. Both subjects presented improvements in the investigated variables. The proposed model is appropriate for the scientific study of Yoga.
\end{abstract}

Volume 9 Issue I - 2019

\author{
Jose Luis Rosario PT, Jose Roberto Leite \\ Department of Psychobiology, Federal University of São Paulo \\ - UNIFESP, Brazil
}

Correspondence: Jose Luis Rosario PT, Department of Psychobiology, Federal University of São Paulo-UNIFESP, Brazil, Tel 04023-062, Email ze.fisio@gmail.com

Received: November 29, 2018 | Published: January 24, 2019

\section{Introduction}

Yoga has its origin in India. It aims to promote awareness of body and mind through exercises practiced with focal attention. ${ }^{1-4}$ In recent years, yoga has become increasingly popular in Western cultures $^{5-8}$ Among the many different methods of yoga, the vast majority of schools use the triad base of meditation (dhyana), postures (asanas) and breathing (pranayama). ${ }^{9-12}$

Yoga increases muscle strength, flexibility, range of motion, energy and sleep quality. ${ }^{13,14}$ Yoga also improves hormone levels, immune response, thermoregulation, cardiovascular health, coronary artery disease, hypertension, respiratory functions, bronchial asthma, diabetes. ${ }^{15-24}$ Several studies and systematic reviews have demonstrated the effects of yoga on the improvement of mood disorders, such as depression ${ }^{17,25,26}$ and anxiety. ${ }^{27-34}$ The practice of yoga is associated with a reduced number of episodes of major depression, and lower risk of dysthymia, which is a milder form of depression. ${ }^{11,14,25,27,29,33,35-38}$ The meta-analyses and systematic reviews indicate that both yoga and meditative therapies are equally effective against conventional antidepressants in the treatment of depression and anxiety. ${ }^{39,40}$ Stress and insomnia. ${ }^{18,19}$ Other data suggest that these practices are also associated with changes in response to stress and anxiety. ${ }^{41-43}$ Besides, the positive effects of yoga have been proven to increase the sense of well being and satisfaction with life. ${ }^{13,44}$

Some people may find yoga practice more attractive than pharmacological therapies because it allows practitioners to participate in therapy actively. Yoga can also be an ally in periods of significant anxiety or depression, which enables the individual to selfmanage. Also, the practice of yoga may be perceived as something that does not 'artificially' affect biochemical processes in the same way as pharmaceutical interventions.

Yoga is a comprehensive practice where there are different types of meditation and more than 500 asanas or postures. This enormous amount of asanas is excellent for varying exercises for practitioners or dosing the activity level based on experience, age or level of physical condition. On the other hand, it is tough to obtain a scientific standardization to study the effects of the practice once the possibilities are vast and may be difficult to reproduce. In this way, the present work had as objective to test an easy teaching method of meditation and asanas for better reproducibility and application in any group even without previous experience with yoga.

\section{Methodology}

Two male subjects, one of 51 the other 54, male, healthy, medication free, bachelor degree holders, free from neurological or psychiatric problems, participated in this case study. Before the first Yoga session, participants had their blood pressure $(\mathrm{mmHg})$ measured with a sphygmomanometer and heart rate measured by the wrist pulse in beats per minute (bpm). Also, they had their global stretch measured using the third finger soil test. This test is performed in standing position. The subject flexes the trunk with the knees extended. The distance between the third finger and the floor in centimeters is measured with a measuring tape. The smaller the distance between the finger and ground the better.

Both participants went through 8 training sessions, 1 per week, 30minutes for meditation and 30 minutes for asanas. In these sessions, they learned the foundations of Progressive Self-focal Meditation and increased the asanas' difficulty progressively. They underwent the same assessment 24 hours after the eighth Yoga session.

\section{Progressive Self-focal Meditation (PSM)}

Week 1 and 2 Diaphragmatic Breathing is a deep and slow, predominantly abdominal breathing exercise, avoiding chest movements. Week 3 and 4 Progressive muscle relaxation participants will be instructed to contract small muscle groups, observe muscle contraction, and then induce relaxation of the body. This procedure will be performed gradually so that the body achieves complete relaxation at the end of the exercise.

Week 5 and 6 - Shalom - Two cards are used for this meditation exercise. One with the word SHALOM written and another with the following instructions: "Watch the card for a few seconds. Close your eyes and visualize the word SHALOM on your screen mental "At the same time, do the diaphragmatic breathing as follows: inhale, focus on the" sha "(at this moment without any sound), exhale and, with your lips closed, vocalize" lom", producing a buzzing and vibration which spreads from the throat to the nose, ears, forehead, and the entire area of the skull. Exhale should last twice as long as inspiration."

Weeks 7 and 8 Meditation on the flow of thoughts this meditation consists of focusing the flow of thoughts without analysis, judgment, or engaging with them. In the case of persistent thinking blocking the flow, participants will be invited to use the "Shalom" mantra to return to their spontaneous flow of thoughts. 


\section{Asanas}

Asanas are the postures of Yoga. The asanas used in this work were as follows, described by Taccolini ${ }^{45}$

a. Ardha (Half) Bhadrasana (Gracious Pose)

b. Rája (Royal) Padasana (Standing Pose)

c. Raja (Royal) Prathanasana (Pray Pose)

d. Sukha (Happiness or Easy) Vrikshasana (Tree Pose)

e. Sukha (Happiness or Easy) Janurdhwa (Knee) Shirshasana (Head Pose)

f. Grivel (Neck) Vartenasana (Spinning Pose)

g. Bahuvartenasana (Shoulder Raising Pose)

h. Raja (Royal) Trikonasana (Triangle Pose)

i. Raja (Royal) Hastinasana (Elephant Dance Pose)

j. Vajra (Indra's thunderbolt) Hamsasana (Swam Pose) k. Raja (Royal) Dharanasana (Bow Pose)

1. Ardha (Half) Bhujangasana (Snake Pose)

m. Uttara (North) Shavasana (Corpse Pose)

n. Sukha (Happiness or Easy) Bahupadasana (Foot Arm Pose)

o. Raja (Royal) Bahupadasana (Foot Arm Pose)

p. Ekapada (One foot) Chalanasana (Churning Pose)

Asanas progressed from the easiest to the most difficult according to Table 1.

\section{Results}

Both subjects had a decrease in the value of the observed variables, according to Table 2 .

Subject 1 had a better improvement in general stretching, while subject 2 had a better decrease in the heart rate. Blood pressure had a significant and similar decrease for both subjects.

Table I Weekly progression of Asanas

\begin{tabular}{|c|c|c|c|c|c|c|c|}
\hline Week 1 & Week 2 & Week 3 & Week 4 & Week 5 & Week 6 & Week 7 & Week 8 \\
\hline Ardha & Ardha & Ardha & Ardha & Ardha & Ardha & Ardha & Ardha \\
\hline Bhadrasana & Bhadrasana & Bhadrasana & Bhadrasana & Bhadrasana & Bhadrasana & Bhadrasana & Bhadrasana \\
\hline $\begin{array}{l}\text { Healthy Raja } \\
\text { Pada }\end{array}$ & Raja Padasana & $\begin{array}{l}\text { Raja } \\
\text { prathanasana }\end{array}$ & $\begin{array}{l}\text { Raja } \\
\text { prathanasana }\end{array}$ & $\begin{array}{l}\text { Sukha } \\
\text { Vrikshasana }\end{array}$ & $\begin{array}{l}\text { Sukha } \\
\text { Vrikshasana }\end{array}$ & $\begin{array}{l}\text { Sukha } \\
\text { Janurdhwa } \\
\text { shirshasana }\end{array}$ & $\begin{array}{l}\text { Sukha } \\
\text { Janurdhwa } \\
\text { shirshasana }\end{array}$ \\
\hline Griva & Griva & Griva & Griva & Griva & Griva & Griva & Griva \\
\hline Vartenasana & Vartenasana & Vartenasana & Vartenasana & Vartenasana & Vartenasana & Vartenasana & Vartenasana \\
\hline Bahuvartenasana & Bahuvartenasana & Bahuvartenasana & Bahuvartenasana & Bahuvartenasana & Bahuvartenasana & Bahuvartenasana & Bahuvartenasana \\
\hline Raja & Raja & Raja & Raja & Raja & Raja & Raja & Raja \\
\hline Trikonasana 1 & Trikonasana 1 & Trikonasana 1 & Trikonasana 2 & Trikonasana 2 & Trikonasana 2 & Trikonasana 3 & Trikonasana 3 \\
\hline Healthy Hastina & Hastinasana & Hastinasana & Hastinasana & Hastinasana & Hastinasana & Hastinasana & Hastinasana \\
\hline $\begin{array}{l}\text { Vajra } \\
\text { ham sasana }\end{array}$ & $\begin{array}{l}\text { Vajra } \\
\text { ham sasana }\end{array}$ & $\begin{array}{l}\text { Vajra } \\
\text { ham sasana }\end{array}$ & $\begin{array}{l}\text { Vajra } \\
\text { hamasasana }\end{array}$ & $\begin{array}{l}\text { Raja } \\
\text { dharanasana }\end{array}$ & $\begin{array}{l}\text { Raja } \\
\text { dharanasana }\end{array}$ & $\begin{array}{l}\text { Raja } \\
\text { dharanasana }\end{array}$ & $\begin{array}{l}\text { Raja } \\
\text { dharanasana }\end{array}$ \\
\hline $\begin{array}{l}\text { Ardha } \\
\text { Bhujangasana }\end{array}$ & $\begin{array}{l}\text { Ardha } \\
\text { Bhujangasana }\end{array}$ & $\begin{array}{l}\text { Ardha } \\
\text { Bhujangasana }\end{array}$ & $\begin{array}{l}\text { Ardha } \\
\text { Bhujangasana }\end{array}$ & $\begin{array}{l}\text { Ardha } \\
\text { Bhujangasana }\end{array}$ & $\begin{array}{l}\text { Ardha } \\
\text { Bhujangasana }\end{array}$ & $\begin{array}{l}\text { Ardha } \\
\text { Bhujangasana }\end{array}$ & $\begin{array}{l}\text { Ardha } \\
\text { Bhujangasana }\end{array}$ \\
\hline $\begin{array}{l}\text { Uttara } \\
\text { Shavasana } \\
\text { Sukha } \\
\text { bahupadaheals }\end{array}$ & $\begin{array}{l}\text { Uttara } \\
\text { Shavasana } \\
\text { Sukha } \\
\text { bahupadaheals }\end{array}$ & $\begin{array}{l}\text { Uttara } \\
\text { Shavasana } \\
\text { Sukha } \\
\text { bahupadaheals }\end{array}$ & $\begin{array}{l}\text { Uttara } \\
\text { Shavasana } \\
\text { Sukha } \\
\text { bahupadaheals }\end{array}$ & $\begin{array}{l}\text { Uttara } \\
\text { Shavasana } \\
\text { Sukha } \\
\text { bahupadaheals }\end{array}$ & $\begin{array}{l}\text { Uttara } \\
\text { Shavasana } \\
\text { Sukha } \\
\text { bahupadaheals }\end{array}$ & $\begin{array}{l}\text { Uttara } \\
\text { Shavasana } \\
\text { Raja } \\
\text { bahupadasana }\end{array}$ & $\begin{array}{l}\text { Uttara } \\
\text { Shavasana } \\
\text { Raja } \\
\text { bahupadasana }\end{array}$ \\
\hline & & & & Chalana sana & Chalanasana & Chalanasana & Chalanasana \\
\hline
\end{tabular}

Table 2 Comparison between pre and post-treatment evaluation for both subjects for the variables: blood pressure $(\mathrm{mmHg})$, heart rate $(\mathrm{bpm})$ and general stretching $(\mathrm{cm})$

\begin{tabular}{lllllll}
\hline & \multicolumn{2}{l}{ Blood pressure $(\mathbf{m m H g})$} & \multicolumn{2}{l}{ Heart Rate $(\mathbf{b p m})$} & \multicolumn{2}{l}{ General stretching $(\mathbf{c m})$} \\
& Before & After & Before & After & Before & After \\
\hline Subject 1 & $142 \times 83$ & $132 \times 83$ & 102 & 96 & 15.3 & 11.2 \\
Subject 2 & $138 \times 80$ & $131 \times 81$ & 105 & 91 & 9.0 & 7.8 \\
\hline
\end{tabular}

\section{Discussion}

This work corroborates with others who showed a decrease in stress ${ }^{16,32}$ and anxiety, ${ }^{39,46,40}$ although our study did not evaluate these characteristics directly. However, the decrease in blood pressure and heart rate are usually linked to the relief of stress and anxiety.

Some other studies have had similar results to those of this paper. ${ }^{20,28}$ Nevertheless, this was only a pilot study, which also serves as a case study, to evaluate the efficiency of the protocol presented.
The results of a case study alone are weak to suggest that Yoga is beneficial in those conditions. On the other hand, other works with larger groups, statistic, and control group obtained the same result.

The 8-week treatment protocol for teaching PSM and a simple sequence of asanas worked well since practitioners were able to learn the postures and meditation in the proposed time, to handle more difficult exercises for both types of techniques, and obtain positive health related results. This work covered meditation (PSM) and postures (asanas). A model for teaching breathing (pranayama) 
is required to complete the Yoga most commonly used types of exercises. ${ }^{47-66}$

\section{Conclusion}

The methodology of learning, studying and standardizing meditation and asanas worked well for our small sample. The next step is to do the same with a larger number of participants. While we obtained evidence of improvements in the variables studied, it is not possible to affirm based on our results that Yoga brings improvement to heart rate, blood pressure and stretching. In our next work, with a larger sample and control group, we can affirm the result to be obtained with greater security.

\section{Acknowledgments}

None.

\section{Conflicts of interest}

The author declares that there is no conflicts of interest.

\section{References}

1. Bock M, Wapenaar M. Yoga voor dag en nacht, praktische oefeningen Rotterdam: BBNC. 2010.

2. Keengan L. Healing with complementary \& alternative therapies. Delmar Thomson Learning, Albany, USA; 2001.

3. Feuerstein G. The Yoga Tradition, Hohm Press: Prescott, 1998.

4. Iyengar BKS. Light on Yoga, Schocken Books: USA;1966.

5. Ding, D, Stamatakis E. Yoga practice in England 1997e2008: prevalence, temporal trends, and correlates of participation. BMC Res Notes. 2014;7:172

6. Ospina MB, Bond $\mathrm{K}$, Karkhaneh M, et al., Meditation practices for health: state of the research. Evid Rep Technol Assess (Full Rep.) 2007;(155):1-263

7. Lutz A DJ, Davidson RJ. Meditation and the neuroscience of consciousness. In: ZP, editors. Cambridge Handbook of Consciousness. Cambridge: Cambridge University Press; 2007. p. 499-554.

8. Tindle HA, Davis RB, Phillips RS et al. Trends in use of complementary and alternative medicine by us adults:1997-2002. Altern. Ther. Health Med. 2005;11(1):42-49.

9. Farmer J. Yoga body: the origins of modern posture practice. Rev Am Hist. 2012;40(1):145e158.

10. Pflueger LW. Yoga body: the origins of modern posture practice. Relig Stud Rev. 2011;37(3):235e235

11. Mehta P, Sharma M. Yoga as a Complementary Therapy for Clinical Depression. Journal of Evidence-Based Complementary \& Alternative Medicine. 2010;15(3):156-170.

12. Travis F, Pearson C. Pure consciousness: distinct phenomenological and physiological correlates of "consciousness itself". Int J Neurosci. 2000;100(1-4):77-89.

13. Ray US, Mukhopadhyaya S, Purkayastha SS, et al. Effect of yogic exercises on physical and mental health of young fellowship course trainees. Indian J Physiol Pharmacol. 2001;45(1):37-53.

14. Pilkington K, Kirkwood G, Rampes H, et al. Yoga for depression: The research evidence. J Affect Disord. 2005;89(1-3):13-24.

15. Udupa KN, Singh RH, Settiwar RM. Physiological and biochemical studies on the effect of yoga and certain other exercises. Ind J Med Res. 1975;63(4):620-624.
16. Selvamurthy W, Nayar HS, Joseph NT, Joseph S. Physiological responses to cold $\left(10^{\circ}\right)$ in man after six months of yoga exercise. Int $J$ Biomet. 1983;32:188-193.

17. Selvamurthy W, Nayar HS, Joseph NT, et al. Physiological effects of yogic practices. NIMHANS. 1983;1:71-75.

18. Selvamurthy W, Sridharan K, Ray US, et al. A new physiological approach to control essential hypertension. Indian $J$ Physiol Pharmacol. 1998;42(2):205-213.

19. Murugesan R, Govindarajulu N, Bera TK. Effect of selected yogic practices on the management of hypertension. Indian J Physiol Pharmacol. 2000;44(2):207-210.

20. Sathyaprabha TN, Murthy H, Murthy BT. Efficacy of naturopathy and yoga in bronchial asthma-A self controlled matched scientific study. Indian J Physiol Pharmacol. 2001;45(1):80-86.

21. Telles S, Naveen KV. Yoga for rehabilitation: An overview. Indian J Med Sci. 1997;51(4):123-127.

22. Manchanda SC, Narang R, Reddy KS, et al. Retardation of coronary atherosclerosis with yoga lifestyle intervention. $J$ Assoc Physicians India. 2000;48(7):687-694

23. Ornish D, Scherwitz LW, Billings JH, et al. Intensive lifestyle changes for reversal of coronary heart disease. JAMA. 1998;280(23):20012007.

24. Uebelacker LA, Epstein-Lubow G, Gaudiano BA, et al. Hatha yoga for depression: Critical review of the evidence for efficacy, plausible mechanisms of action, and directions for future research. Journal of Psychiatric Practice. 2010;16(1):22-33.

25. Balasubramaniam M, Telles S, Doraiswamy PM. Yoga on our minds a systematic review of yoga for neuropsychiatric disorders. Front Psychiatry. 2012;3:117.

26. Chattha R., Raghuram N, Venkatram P, et al. Treating the climacteric symptoms in Indian women with an integrated approach to yoga therapy: a randomized control study. Menopause. 2008;15(5):862-870.

27. Granath J, Ingvarsson S, von Thiele U, et al. Stress management: a randomized study of cognitive behavioural therapy and yoga. Cogn Behav Ther. 2006;35(1):3-10.

28. Banerjee, B., Vadiraj HS, Ram A, et al. Effects of an integrated yoga program in modulating psychological stress and radiation-induced genotoxic stress in breast cancer patients undergoing radiotherapy. Integr Cancer Ther. 2007;6(3):242-250.

29. Harinath K, Malhotra AS, Pal K, et al. Effects of Hatha yoga and Omkar meditation on cardiorespiratory performance, psychologic profile, and melatonin secretion. J Altern Complement Med. 2004;10(2):261-268.

30. Kjellgren A, Bood SA, Axelsson K, et al. Wellness through a comprehensive yogic breathing program e a controlled pilot trial. BMC Complement Altern Med. 2007;7:43.

31. West J, Otte C, Geher K, et al. 2004. Effects of Hatha yoga and African dance on perceived stress, affect, and salivary cortisol. Ann Behav Med. 2004;28(2):114-118.

32. Woolery A, Myers H, Sternlieb B, et al. A yoga intervention for young adults with elevated symptoms of depression. Altern Ther Health Med. 2004; 10(2):60-63.

33. Li AW, Goldsmith CA. The effects of yoga on anxiety and stress Altern Med Rev. 2012;17(1):21-35.

34. John PJ, Sharma N, Sharma CM. Effectiveness of yoga therapy in the treatment of migraine without aura: a randomized controlled trial. Headache. 2007;47(5):654-661.

35. Sharma VK, Das S, Mondal S, et al. Effect of Sahaj Yoga on neurocognitive functions in patients suffering from major depression. Indian J Physiol Pharmacol. 2006;50(4):375-383. 
36. Butler LD, Waelde LC, Hastings TA, et al. Meditation with yoga, group therapy with hypnosis, and psychoeducation for long-term depressed mood: a randomized pilot trial. J Clin Psychol. 2008;64(7):806-820.

37. Cramer H, Lange S, Klose P, et al. Yoga for breast cancer patients survivors: A systematic review and meta-analysis. BMC Cancer. 2012;12:412.

38. da Silva T.L, Ravindran LN, Ravindran AV. Yoga in the treatment of mood and anxiety disorders: a review. Asian J Psychiatr. 2009;2 (1):6-16.

39. Chen KW, Berger CC, Manheimer E, et al. Meditative therapies for reducing anxiety: a systematic review and meta-analysis of randomized controlled trials. Depress Anxiety. 2012;29(7):545-562.

40. Kinser PA, Goehler LE, Taylor AG. How might yoga help depression? a neurobiological perspective. Explore J Sci Heal. 2012;8(2): 118-126.

41. Mc Call MC. How might yoga work? An overview of potential underlying mechanisms. Yoga Phys Ther. 2013;3(1).

42. Long L, Huntley A, Ernst E. Which complementary and alternative therapies benefit which conditions? A survey of the opinions of 223 professional organizations. Complementary Ther Med. 2001;9(3):178185.

43. Impett EA, Daubenmier JJ, Hirschman LA. Minding the Body: Yoga, Embodiment, and Well-Being. Journal of Sexuality Research \& Social Policy. 2006;3(4):39-48.

44. Taccolini M. 108 Famílias de Asanas do Yoga: Edição Núcleo de Estudos Yoga Natarája. 2002.

45. Cramer H, Lauche R, Langhorst J, et al. Yoga for depression: a systematic review and meta-analysis. Depress Anxiety. 2013;30(11):1068-1083.

46. Akbulut KG, Gonul B, Akbulut H. The effects of melatonin on humoral immune responses of young and aged rats. Immunol Invest. 2001;30:17-20

47. Clarke TC, Black LI, Stussman BJ, et al. Trends in the use of complementary health approaches among adults: United States, 2002e2012. Natl Health Stat Rep. 2015;10(79):1-16.

48. D’Silva S, Poscablo C, Habousha R, et al. Mind-body medicine therapies for a range of depression severity: a systematic review. Psychosomatics. 2012;53(5):407-423.

49. Gitto E, Tan DX, Reiter RJ, et al. Individual and synergistic antioxidative actions of melatonin: Studies with vitamin E, vitamin $\mathrm{C}$, glutathione and desferrioxamine (desferoxamine) in rat liver homogenates. J Pharm Pharmacol. 2001;53(10):1393-1401.

50. Hoyos M, Guerrero JM, Perez-Cano R, et al. Serum cholesterol and lipid peroxidation are decreased by melatonin in diet-induced hypercholesterolemic rats. J Pineal Res. 2000;28(3):150-155.

51. Issakidis, C., Andrews, G., 2002. Service utilisation for anxiety in an Australian community sample. Soc. Psychiatry Psychiatr. Epidemiol. 37(4):153-163.
52. James SP, Medeleson WB, Sack DA, et al. The effect of melatonin on normal sleep. Neuropsychopharmacology. 1987;1(1):41-44.

53. Jorm AF, Christensen H, Medway J, et al. Public belief systems about the helpfulness of interventions for depression: associations with history of depression and professional help-seeking. Soc Psychiatry Psychiatr Epidemiol. 2000;35(5):211-219.

54. Jorm AF, Medway J, Christensen H, et al. Public beliefs about the helpfulness of interventions for depression: effects on actions taken when experiencing anxiety and depression symptoms. Aust NZJ Psychiatry. 2000;34(4):619-626.

55. Joseph S, Sridharan K, Patil SKB, et al. Study of some physiological and biochemical parameters in subjects undergoing yogic training. Ind J Med Res. 1981;74:120-124.

56. Kitajima T, Kanbayashi T, Saitoh Y, et al. The effects of oral melatonin on the autonomic function in healthy subjects. Psychiatry Clin Neurosci. 2001;55(3):299-300.

57. Kornblihtt LI, Finocchiaro L, Molinas FC. Inhibitory effect of melatonin on platelet activation induced by collagen and arachidonic acid. J Pineal Res. 1993;14(4):184-191.

58. McCall MC.How might yoga work? an overview of potential underlying mechanisms. Yoga Phys Ther. 2013;3(1).

59. Monk-Turner, Turner C. Does yoga shape body, mind and spiritual health and happiness: Differences between yoga practitioners and college students. Int J Yoga. 2010;3(2):48-54.

60. Nayar HS, Mathur RM, Kumar RS. Effects of yogic exercises on human physical efficiency. Ind J Med Res. 1975;63(10):1369-1373.

61. Nerurkar A, Yeh G, Davis RB, et al. When conventional medical providers recommend unconventional medicine: results of a national study. Arch Intern Med. 2011;171(9):862-864.

62. Penman S, Cohen M, Stevens P, et al. Yoga in Australia: results of a national survey. Int J Yoga. 2012;5(2):92-101.

63. Riley D. Hatha yoga and the treatment of illness (commentary). Alter Ther in Health and Med. 2004;10(2):20-21.

64. Smith C, Hancock H, Blake-Mortimer J, et al. A randomised comparative trial of yoga and relaxation to reduce stress and anxiety. Complement Ther Med. 2007;15(2):77-83.

65. Waldhauser F, Saletu B, Trinchard LI. Sleep laboratory investigations on hypnotic properties of melatonin. Psychopharmacol. 1990;100(2):222-226.

66. Wardle J, Adams J, Sibbritt D. Referral to yoga therapists in rural primary health care: a survey of general practitioners in rural and regional New South Wales, Australia. Int J Yoga. 2014;7(1):9-16. 